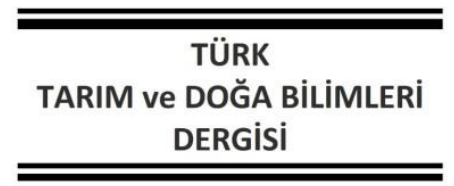

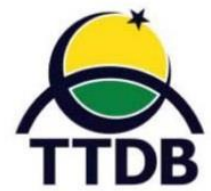

www.dergipark.gov.tr/turkjans

Araştırma Makalesi

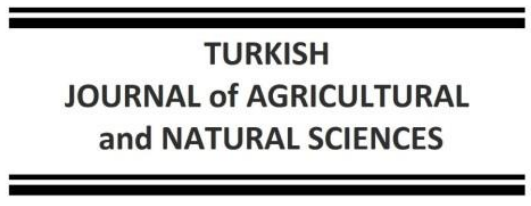

and NATURAL SCIENCES

\title{
Fasulyede Tarımsal Özelliklerin Kalıtımlarının Çoklu Dizi Analiz Metoduyla Belirlenmesi
}

\author{
Ercan CEYHAN ${ }^{1 *}$, Duran ŞIMŞEK ${ }^{2}$ \\ ${ }^{1}$ Selçuk Üniversitesi, Ziraat Fakültesi, Tarla Bitkileri Bölümü, Konya \\ ${ }^{2}$ Areo Tohumculuk Ar-Ge San. ve Dış. Tic. A.Ş., Antalya \\ *Sorumlu Yazar: eceyhan@selcuk.edu.tr
}

Geliş Tarihi: 21.12.2020 Düzeltme Geliş Tarihi: 16.01.2021 Kabul Tarihi: 16.01.2021

Öz

Önemli tarımsal özelliklerin kalıtımlarının ortaya konulması ıslah çalışmalarının başarısı için elzemdir. Çalışmanın amacı fasulyede önemli tarımsal karakterlerin kalıtımlarının belirlenmesidir. Araştırmada iki adet kuru dane fasulye (Great Northern 59 ve Alberto) çeşidi ve bir adet ateş fasulyesi (İspanyol, Bombay fasulyesi) (Phaseolus coccineus L.) baba olarak ve 6 fasulye (PV04035, PV04086, PV04092, PV04145, PV05001 ve PV05023) hattı ise ana olarak kullanılmıştır. F2 populasyonu ve ebeveynler 2019 yılında Selçuk Üniversitesi Tam Kontrollü Bitki Islah Serasında yetiştirilmiştir. Çalışmada tane verimi ve bazı tarımsal özellikleri için ebeveyn ve $F_{2}$ populasyonlarında çoklu dizi analiz yöntemiyle genel ve özel kombinasyon yetenekleri, heterosis ve heterobeltiosis değerleri, geniş ve dar anlamda kalıtım dereceleri ve özellikler arası ilişkiler tespit edilmiştir. Tane veriminin kalıtımında eklemeli olmayan gen etkilerin etkili olduğu belirlenmiştir. Heterosis ve heterobeltiosis değerleri tane verimi $F_{2}$ populasyonları için pozitiftir. Araştırmada kuru fasulye ıslahında kullanılabilecek bazı tarımsal özellikler için uygun ebeveyn ve melezler kombinasyonları belirlenmiştir.

Anahtar kelimeler: Fasulye, çoklu dizi analizi, GKK, kalıtım, ÖKK

\section{Heredity of Agricultural Characters Determined Through Line X Tester Method in Bean}

\begin{abstract}
Elucidation of inheritance of agronomic characters is crucial for the success of plant breeding. The aim of the study is to determine the inheritance of agronomic characters in bean. Two dry bean (Great Northern 59 and Alberto) and one runner bean (Phaseolus coccineus L.) were crossed with six bean lines (PV04035, PV04086, PV04092, PV04145, PV05001 and PV05023) to get 18 hybrid combinations. The $F_{2}$ populations along with the parents were evaluated in a fully-automated plant breeding greenhouse of Selcuk University in 2019. For seed yield and other agricultural traits, line $x$ tester analysis method was employed to determine general combining ability (GCA) and specific combining ability (SCA), heterosis and heterobeltiosis values, broad and narrow sense heritability and correlations among the traits. For seed yield, non-additive gene effects were important. Heterosis and heterobeltiosis values for seed yield were positive. Compatible parents that can be used in future bean breading programs were determined for the agriculture characters.
\end{abstract}

Key words: Bean, line $x$ tester analysis, GCA, heredity, SCA

\section{Giriş}

Fasulyenin (Phaseolus vulgaris L.) gen merkezi yeni dünya ve Asya olduğu için sıcak ve ılıman iklime sahip yerlere iyi adapte olduğu ve dünyada çok geniş ekim alanlarına sahip olduğu bilinmektedir. Fasulye bitkisi çimlenme döneminde sıcak, çiçeklenme döneminde ise kurağa ve düşük neme son derce hassastır (Şehirali, 1988). Dünyada gelir düzeyi düşük olan ülkelerin beslenmesinde en önemli bitkilerin başında fasulye gelirken (Aragao ve Brasileiro, 1995) ülkemizde ise insanlarımızın beslenmesinde çok önemli protein ve karbonhidrat kaynağı ilk sıralarda yer almaktadır. Son yıllarda artık protein kaynağı olan besin maddelerinin insan beslenmesindeki önemi bilinmektedir. Fasulye taneleri \% 22-30 gibi yüksek miktarda protein bulundurması, karbonhidratlarca zengin; potasyum, kalsiyum, magnezyum ve fosforca yeterli ve çeşitli 
vitaminler bakımından iyi bir bitkisel protein kaynağıdır (Akçin 1988).

Kuru dane fasulye melezlerinde bitki boyu, bitkide bakla sayısını ve tane verimi özelliklerinde yüksek genel kombinasyon kabiliyeti (GKK) ve özel kombinasyon kabiliyeti (ÖKY) Singh ve Urrea (1994), Oliveira Junior ve ark. (1997), Ceyhan ve ark. (2014) ve Tamüksek ve Ceyhan (2020) tarafından bildirilmiştir. Yerel genotipler bu tip Islah programlarında temel ıslah kaynağı olarak kullanılabilir (Oliveira Junior ve ark., 1997; Ceyhan ve ark., 2014).

Fasulyede tane verimi ve hasat indeksinin eklemeli genler (Zimmermann ve ark., 1985; Singh ve Urrea, 1994; Oliveira Junior ve ark., 1997; Rodrigues ve ark., 1998; Barelli ve ark., 2000), baklada yumurtalık sayısının bir tek gen allelinin eklemeli etkisi altında (Al-Mukhtar ve Coyne, 1981), ayrıca tane verimi, bakla özelikleri ve bitki boyunun kalıtımında eklemeli olmayan genlerin (Rodrigues ve. ar., 1998; Ceyhan ve ark., 2014 ve Tamüksek ve Ceyhan, 2020) etkili olduğu bilinmektedir.

Dünyada fasulye bitkisinin yetiştiriciliğini sınırlayan en önemli iklim faktörünün sıcaklık olduğu bilinmektedir (Akçin, 1988). Yaz aylarında sıcaklığın $10^{\circ} \mathrm{C}^{\prime}$ nin altına düşen bölgelerde baklaları olgunlaşamamakta, günlük sıcaklığın $32{ }^{\circ} C^{\prime}$ nin üzerine çıktığı yerlerde ise çiçeklerini dökmektedir (Şehirali, 1988). Ülkemizin tüm bölgelerinde fasulye tarımı yapılmakta ise de fasulye tarımının en fazla yapıldığı bölge Orta Anadolu Bölgesi'dir. Ekim alanları düşünüldüğünde ülkemizde fasulye tarımının en yoğun olarak Orta Anadolu bölgesinde yapılmasına rağmen (Ceyhan, 2004), ortalama verimi Türkiye ortalamasının altında gerçekleşmektedir. Bunun en önemli nedenlerinin başında tescilli çeşitlerin bazı stres şartlara dayanıksız (kuraklık, nisbi nem, hastalık vb.) olması ve bölgeye adapte olamaması nedeniyle bölge çiftçisi tarafından tercih edilmemesidir. Bu çalışmanın amacı fasulyede önemli agrnomik karakterlerin kalıtımını ortaya koymaktır.

\section{Materyal ve Metot}

Araştırmada, iki adet kuru dane fasulye (Phaseolus vulgaris L.) (Great Northern 59 ve Alberto) çeşidi ve bir adet ateş fasulyesi (İspanyol, Bombay fasulyesi) (Phaseolus coccineus L.) baba ve 6 fasulye (Phaseolus vulgaris L.) hattı ise ana olarak kullanılarak melezleme yapılmıştır. Melezleme işlemi Ceyhan (2003)'e göre yapılmıştır. Melezleme işlemi Line $x$ Tester metoduna göre $6 \times 3$ olacak şekilde yapılmıştır. $\mathrm{Bu}$ melezlemelerde ıslah amaçlarımıza uygun ebeveynler kullanılmıştır. Araştırmada özellikle yüksek sıcaklığa dayanıklı saf hatlar (PV04035, PV04086, PV04092 ve PV04145) ile hassas saf hatlar (PV05001 ve PV05023) ana olarak kullanılmıştır. Ayrıca Baba olarak kullanılan Alberto ve Great Northern 59 çeşitleri bölgede en fazla ekimi yapılan ve erkenci olan çeşitlerdir.

$F_{1}$ bitkilerinden elde edilen $F_{2}$ populasyona ait melez tohumlarının 180 adeti ve ebeveynler yine sera şartlarında yetiştirilmiştir. Sera denemesi "Tesadüf Blokları Deneme" desenine göre üç tekerrürlü olarak "Selçuk Üniversitesi Tam Kontrollü Bitki Islah Serası"nda kurulmuştur. Parseller $2 \mathrm{~m}$ boyunda ve her parsel üç sıradan oluşmuştur. Ekim işlemi sıra arası $50 \mathrm{~cm}$ ve sıra üzeri $10 \mathrm{~cm}$ olacak şekilde 30 Mart 2019 tarihinde yapılmıştır. Deneme alanına dekara $15 \mathrm{~kg}$ olacak şekilde DAP (Diamonyum Fosfat) gübresi verilmiştir. Deneme süresince yabancı otlarla mücadele için 3 defa çapalama yapılmıştır. Bitkilerin su ihtiyaçları damlama sulama ile karşılanmış ve 6 defa sulama işlemi gerçekleştirilmiştir. Ağustos ayı içerisinde bitkilerin \% 90 olgunlaştığında hasat işlemi gerçekleştirilmiştir. Fasulye bitkisinin yetiştirilme mevsiminde seranın sıcaklığı gündüzleri $25 \stackrel{\circ}{ } \mathrm{C} \pm 5$, geceleri $18 \stackrel{\circ}{ } \mathrm{C} \pm 5$ olacak şekilde kontrol edilmiştir. Ayrıca seranın rüzgar hızı $5 \mathrm{~km} /$ saat ve nisbi nem \% 50-55 arasında sabit olacak şekilde ayarlanmıştır. Araştırma tam kontrollü şartlarda yürütülmüştür.

Araştırmada incelenen özelliklere ait ölçüm ve sayımlar ebeveyn ve $F_{2}$ populasyonlarında her parselde 5 bitkiden elde edilmiştir. Araştırmada üzerinde durulan özellikler ait verilerin alınışı Ceyhan (2003) göre yapılmıştır. Araştırmada $F_{2}$ bitkileri üzerinde yapılan gözlem, ölçümlerden elde edilen veriler "Tesadüf Blokları Deneme" desenine göre ön varyans analizine tabi tutulmuştur. Melezler arasında varyasyon tespit edilen tarımsal özelliklerde çoklu dizi (line $\mathrm{x}$ tester) analizi uygulanmıştır (Kempthorne 1957, Sing ve Chaudhary 1979).

\section{Bulgular ve Tartışma}

Araştırmada $F_{2}$ popülasyonun da incelenen tane verimi ve bazı tarımsal özelliklere ait çoklu dizi varyans analizi kareler ortalaması Çizelge 1'de, genel ve özel kombinasyon varyansları bunların genetik parametreleri Çizelge 2'de verilmiştir.

Araştırmada varyans analizi sonuçlarına göre incelenen tüm özellikler için genotiplerin, ebeveynlerin ve melezlerin kareler ortalamalarının istatistiki olarak önemli olduğu belirlenmiştir. Hatlar arasında baklada tane sayısı, tane verimi hariç diğer özelliklerin hepsinde istatistiki olarak önemli farklılıklar bulunmuştur. Tester hatlar arasında ise bakla sayısı hariç diğer tüm özelliklerde istatistiki olarak önemli farklılıklar tespit edilmiştir. Hat $x$ Tester interaksiyonuna ait varyanslar içinde ise bitki boyu hariç diğer tüm özelliklerde istatistiki bakımdan çok önemli farklılıklar belirlenmiştir (Çizelge 1). 
Çizelge 2'den de görüleceği gibi $F_{2}$ populasyonunda bu çalışmada incelenen tüm özelliklerin [?2' GKK/ ?20̈OKK oranlarının 1'den küçük ve $(H / D)^{1 / 2}$ oranın da $1^{\prime}$ den büyük çıkması bize eklemeli olmayan gen etkisinin yani dominant gen etkisinin bu özelliğin kalıtımında etkili olduğunu göstermektedir. Daha önce yapılan çalışmalarda bu sonuçlara benzer sonuçlar Oliveira Junior ve ark. (1997), Barelli ve ark. (2000) ve Ceyhan ve ark.
(2014) tarafından bildirmiştir. Ancak bizim bu çalışmamızın tersine Rodrigues ve ark. (1998), Barelli ve ark. (2000) ve Ceyhan ve ark. (2014) fasulyede bitkide bakla sayısının kalıtımında eklemeli gen etkisinin etkili olduğunu, Zimmermann ve ark. (1985), Singh ve Urrea (1994), Oliveira Junior ve ark. (1997), Rodrigues ve ark. (1998) ve Barelli ve ark. (2000) ise fasulye bitkisinin tane veriminin kalıtımında eklemeli gen etkisinin ve dominant gen etkisinin etkili olduğunu bildirmişlerdir.

Çizelge 1. Fasulye $F_{2}$ populasyonlarında incelenen tane verimi ve bazı verim özellikleri için çoklu dizi analiz metoduyla hesaplanan kareler ortalamaları

\begin{tabular}{lcccc}
\hline Varyasyon Kaynakları & SD & Bitki Boyu & Bakla Sayısı & Baklada Tane Sayısı \\
\hline Tekerrür & 2 & 38.679 & 3.012 & 6.677 \\
Genotipler & 26 & $307.419^{* *}$ & $124.487^{* *}$ & $194.863^{* *}$ \\
Ebeveynler & 8 & $810.843^{* *}$ & $51.093^{* *}$ & $392.385^{* *}$ \\
Melezler & 17 & $105.147^{*}$ & $82.166^{* *}$ & $61.958^{* *}$ \\
Ebev. x Melez İnt. & 1 & 26.080 & $1555.580^{* *}$ & $1068.935^{* *}$ \\
Hatlar & 5 & $52.078^{* *}$ & $160.207^{*}$ & 59.079 \\
Testerler & 2 & $702.722^{* *}$ & 49.019 & $167.126^{*}$ \\
Hat x Testerler İnt. & 10 & 12.167 & $49.774^{* *}$ & $42.364^{*}$ \\
Hata & 52 & 45.538 & 5.141 & 18.217 \\
\hline Varyasyon Kaynakları & SD & Bitkide Tane Sayısı & Yüz Tane Ağırlığ & Tane Verimi \\
\hline Tekerrür & 2 & 168.494 & 0.036 & 6.677 \\
Genotipler & 26 & $1554.832^{* *}$ & $31.694^{* *}$ & $194.863^{* *}$ \\
Ebeveynler & 8 & $643.759^{* *}$ & $76.770^{* *}$ & $392.385^{* *}$ \\
Melezler & 17 & $728.549^{* *}$ & $7.361^{* *}$ & $61.958^{* *}$ \\
Ebev.x Melez İnt. & 1 & $24445.062^{* *}$ & $116.439^{* *}$ & $1068.935^{* *}$ \\
Hatlar & 5 & $1040.844^{*}$ & $13.896^{* *}$ & 59.079 \\
Testerler & 2 & $1665.722^{* *}$ & $17.373^{* *}$ & $167.126^{*}$ \\
Hat x Testerler İnt. & 10 & $384.967^{* *}$ & $2.091^{* *}$ & $42.364^{*}$ \\
Hata & 52 & 52.314 & 0.165 & 18.217 \\
\hline
\end{tabular}

$*: p<0.05 ; * *: p<0.01$

Çizelge 2. Fasulye $F_{2}$ populasyonlarında incelenen özellikler için genel kombinasyon yeteneği varyans tahmini

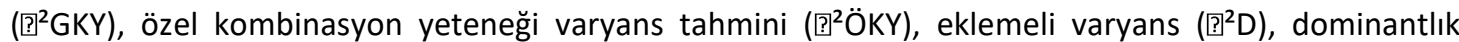
varyans $\left(\mathbb{Q}^{2} \mathrm{H}\right)$ ile oransal ilişkileri

\begin{tabular}{lcccccc}
\hline Özellikler & [? $^{2} \mathrm{GKK}$ & [? $^{2}$ ÖKK & [? $^{2} \mathrm{GKK} /$ ] $^{2}$ ÖKK & [? $^{2} \mathrm{D}$ & [? $^{2} \mathrm{H}$ & $(\mathrm{H} / \mathrm{D})^{1 / 2}$ \\
\hline Bitki Boyu & 2.788 & 67.251 & 0.041 & 5.576 & -11.124 & 1.412 \\
Bakla Sayısı & 0.971 & 26.093 & 0.037 & 1.942 & 14.878 & 2.768 \\
Baklada Tane Sayısı & 0.587 & 23.181 & 0.025 & 1.175 & 8.049 & 2.617 \\
Bitkide Tane Sayısı & 10.301 & 315.764 & 0.033 & 20.603 & 110.884 & 2.320 \\
Yüz Tane Ağırlığı & 0.158 & 3.494 & 0.045 & 0.316 & 0.642 & 1.425 \\
Tane Verimi & 0.587 & 23.181 & 0.025 & 1.175 & 8.049 & 2.617 \\
\hline
\end{tabular}

Bitki boyu: Araştırmada ebeveynlerin bitki boylarının 42.0 (PV04092) ile $96.7 \mathrm{~cm}$ (P. coccineus L.) arasında, $F_{2}$ populasyonlarının bitki boylarının ise $43.3 \mathrm{~cm}$ (PV04145 x Alberto) ile $66.7 \mathrm{~cm}$ (PV04092 x $P$. coccineus L.) arasında değişim gösterdiği belirlenmiştir (Çizelge 3). Daha önce yapılan çalışmalarda Genchev (1995), Ceyhan (2004b), Ceyhan ve Ülker (2008), Ceyhan (2012) ve Tamüksek ve Ceyhan (2020) bizim araştırma sonuçlarına benzer sonuçlar elde etmişlerdir.
Bitki boyu için GKK incelendiğinde tester hatlardan $P$. coccineus pozitif ve önemli $(p<0.01)$ etki gösterirken, Great Northem 59 çeşidi negatif ve önemli ( $p<0.01$ ) etki göstermiştir (Çizelge 3 ).

$F_{2}$ populasyonunda melezlerin ÖKK etkilerine bakıldığında, hiçbir melez kombinasyonu önemli ÖKK etkisine sahip değildir. "PV04092 x Alberto" ve "PV04145 x Alberto" melezleri negatif yüksek ÖKK etkisine sahiplerdir. "PV04092 x Alberto" ve "PV04145 x Alberto" melezleri kısa veya orta bitki boyu için ıslah çalışmalarında kullanılabilecek 
genotipler olarak belirlenmiştir (Tablo 3). Rodrigues ve ark. (1998), Barelli ve ark. (1999), Ceyhan (2004a), Ceyhan ve ark. (2008) ve Tamüksek ve Ceyhan (2020) bitki boyu için ebeveyn ve melezlerin GKK ve ÖKK değerlerinin önemli olduğunu bildirmişler ve bu ebeveyn ve melezlerin bitki boyunu arttırmada ve kısaltmada kullanılabileceklerini belirtmişlerdir.

$\mathrm{F}_{2}$ populasyonunda heterosis değerlerinin \% -19.57 (PV04086 x P. coccineus L.) ile \% 22.97 (PV04092 x Great Northern 59) arasında, heterobeltiosis değerlerinin ise \% -38.97 (PV04145 x P. coccineus L.) ile \% 10.83 (PV04092 x Great Northern 59) arasında değiştiği belirlenmiştir. Ayrıca ortalama heterosis ve heterobeltiosis değerlerinin negatif olması bu popülasyondan orta ve kısa boylu bitkilerin elde edilebileceğini göstermiştir (Çizelge 3). Bitki boyu için heterosis ve heterobeltiosis değerlerini inceleyen Rodrigues ve ark. (1998), Baralli ve ark. (1999), Ceyhan (2003), Ceyhan ve ark. (2008) ve Tamüksek ve Ceyhan (2020) bizim araştırma sonuçlarımıza benzer sonuçlar elde etmişlerdir.

$\mathrm{F}_{2}$ populasyonlarında bitki boyunun geniş anlamda kalıtım derecesinin düşük ve dar anlamda kalıtım derecesinin yüksek çıkması, bu özelliğe çevre varyansının etkisinin düşük olduğu belirtmektedir. Buda bize bitki boyu bakımından seleksiyonun $F_{2}$ generasyondan itibaren yapılabileceğini göstermektedir.

Çizelge 3. Fasulye ebeveyn ve $F_{2}$ populasyonlarında bitki boyuna ait ortalamalar, genel kombinasyon yeteneği (GKK), özel kombinasyon yeteneği (ÖKK), heterosis (Hs), heterobeltiosis ( $\mathrm{Hb}$ ) ve kalıtım dereceleri

\begin{tabular}{|c|c|c|c|c|c|c|c|}
\hline \multicolumn{3}{|c|}{ Ebeveynler } & $\begin{array}{l}\text { Ortalamalar } \\
(\mathrm{cm})\end{array}$ & GKK & ÖKK & $\begin{array}{l}\text { Hs } \\
(\%)\end{array}$ & $\begin{array}{l}\mathrm{Hb} \\
(\%)\end{array}$ \\
\hline \multicolumn{3}{|l|}{ PV04035 } & 46.67 & -0.500 & & & \\
\hline \multicolumn{3}{|l|}{ PV04086 } & 56.67 & 0.167 & & & \\
\hline \multicolumn{3}{|l|}{ PV04092 } & 42.00 & 2.833 & & & \\
\hline \multicolumn{3}{|l|}{ PV04145 } & 46.00 & -4.278 & & & \\
\hline \multicolumn{3}{|l|}{ PV04001 } & 46.67 & 1.500 & & & \\
\hline \multicolumn{3}{|l|}{ PV04023 } & 54.00 & 0.278 & & & \\
\hline \multicolumn{3}{|c|}{ Phaseolus coccineus L. } & 96.67 & $6.944^{* *}$ & & & \\
\hline \multicolumn{3}{|l|}{ Alberto } & 52.33 & -1.778 & & & \\
\hline \multicolumn{3}{|c|}{ Great Northern 59} & 49.67 & $-5.167 * *$ & & & \\
\hline \multicolumn{8}{|c|}{$\mathrm{F}_{2}$ Melezleri } \\
\hline \multicolumn{3}{|c|}{ PV04035 x P. coccineus L. } & 61.33 & & -0.833 & -14.42 & $-36.55 * *$ \\
\hline \multicolumn{3}{|c|}{ PV04035 x Great Northern 59} & 52.33 & & -1.111 & 5.72 & 0.00 \\
\hline \multicolumn{3}{|c|}{ PV04035 x Alberto } & 52.00 & & 1.944 & 7.96 & 4.70 \\
\hline \multicolumn{3}{|c|}{ PV04086 x P. coccineus L. } & 61.67 & & -1.167 & -19.57 & $-36.21 * *$ \\
\hline \multicolumn{3}{|c|}{ PV04086 x Great Northern 59} & 53.67 & & -0.444 & -1.53 & -5.29 \\
\hline \multicolumn{3}{|c|}{ PV04086 x Alberto } & 52.33 & & 1.611 & -1.57 & -7.65 \\
\hline \multicolumn{3}{|c|}{ PV04092 x P. coccineus L. } & 66.67 & & 1.167 & -3.85 & $-31.03 * *$ \\
\hline \multicolumn{3}{|c|}{ PV04092 x Great Northern 59} & 58.00 & & 1.222 & 22.97 & 10.83 \\
\hline \multicolumn{3}{|c|}{ PV04092 x Alberto } & 51.00 & & -2.389 & 11.27 & 2.68 \\
\hline \multicolumn{3}{|c|}{ PV04145 x P. coccineus L. } & 59.00 & & 0.611 & -17.29 & $-38.97 * *$ \\
\hline \multicolumn{3}{|c|}{ PV04145 x Great Northern 59} & 52.00 & & 2.333 & 5.76 & -0.64 \\
\hline \multicolumn{3}{|c|}{ PV04145 x Alberto } & 43.33 & & -2.944 & -9.41 & -12.75 \\
\hline \multicolumn{3}{|c|}{ PV05001 x P. coccineus L. } & 63.33 & & -0.833 & -11.63 & $-34.48 * *$ \\
\hline \multicolumn{3}{|c|}{ PV05001 x Great Northern 59} & 54.33 & & -1.111 & 9.76 & 3.82 \\
\hline \multicolumn{3}{|c|}{ PV05001 x Alberto } & 54.00 & & 1.944 & 12.11 & 8.72 \\
\hline \multicolumn{3}{|c|}{ PV05023 x P. coccineus L. } & 64.00 & & 1.056 & -15.04 & $-33.79 * *$ \\
\hline \multicolumn{3}{|c|}{ PV05023 x Great Northern 59} & 53.33 & & -0.889 & 0.31 & -1.23 \\
\hline \multicolumn{3}{|c|}{ PV05023 x Alberto } & 50.67 & & -0.167 & -2.25 & -6.17 \\
\hline LSD \%1 : & 14.733 & Orta & Hs \%: & $h^{2}:$ & 57.89 & SH (Hatlar) : & 5.060 \\
\hline LSD \%5 : & 11.053 & Ortal & $\mathrm{Hb} \%$ : & $\mathrm{H}^{2}:$ & 56.69 & SH (Testerler) : & 2.530 \\
\hline & & & & & & SH (ÖKK) : & 15.179 \\
\hline
\end{tabular}

Bakla sayısı: Bakla sayısı, ebeveyn değerleri 16.00 (PV04092) ile 33.33 (P. coccineus L.) adet/bitki arasında, $F_{2}$ populasyonunda bitkide bakla sayısının 18.7 (V05001 x Great Northern 59) ile 38.7 adet/bitki (PV05023 x P. coccineus L.) arasında değiştiği belirlenmiştir (Çizelge 4). Bu araştırma sonuçları ile Ceyhan (2004), Ülker ve Ceyhan (2008), Varankaya ve Ceyhan (2012) ve Tamüksek ve Ceyhan (2020)'ın yaptığı çalışmalar arasında büyük oranda benzerlik bulunmaktadır. 
GKK incelendiğinde PV04086, PV04023 ve $P$. coccineus $L$. $(p<0.01)$ hatları önemli ve pozitif etkiye sahipken, PV04145, PV04001 ve Great Northern 59 $(p<0.01)$ hatları önemli ve negatif etki göstermiştir (Çizelge 4). Araştırma da GKK etki değeri pozitif ve önemli olan PV04086, PV04023 ve $P$. coccineus L. hatları fasulyede bakla sayısını arttırmada kullanılabilecek ebeveynler olarak önerilebilir.

$\mathrm{F}_{2}$ populasyonunda melezlerin ÖKK etkilerine bakıldığında, "PV04035 x Alberto" ve "PV04086 x Great Northern 59", "PV04092 x Great Northern 59", "PV04145 x P. coccineus L." ( $p<0.01)$, "PV05023 x P. coccineus L." ve "PV04092 x P. coccineus L." $(p<0.05)$ melezleri pozitif ve önemli ÖKK etkisine sahip olurken, "PV04035 x P. coccineus L.", "PV04086 x P. coccineus L.", "PV04092 x Alberto", "PV04145 x Alberto", "PV05001 x Great Northern 59 " ve "PV05023 x Great Northern 59" ( $p<0.01)$ melezi ise negatif ve önemli ÖKK etkisine sahiptir (Çizelge 4). Pozitif ve önemli ÖKK etkisine sahip olan melezler bitkide bakla sayısını artırmada kullanılabilecek uygun genotip olarak belirlenmiştir. Bitkide bakla sayısı ebeveyn ve melezlerin GKK ve ÖKK etkilerini Al-Mukhtar ve Coyne (1981), Rodrigues ve ark. (1998), Barelli ve ark. (2000), Ceyhan (2004), Ceyhan ve ark. (2014) ve Tamüksek ve Ceyhan (2020)' da sonuçlarımızla benzer sonuçlar tespit etmişlerdir.

Çizelge 4. Fasulye ebeveyn ve $F_{2}$ populasyonlarında bakla sayısına ait ortalamalar, genel kombinasyon yeteneği (GKK), özel kombinasyon yeteneği (ÖKK), heterosis ( $\mathrm{Hs})$, heterobeltiosis ( $\mathrm{Hb}$ ) ve kalıtım dereceleri

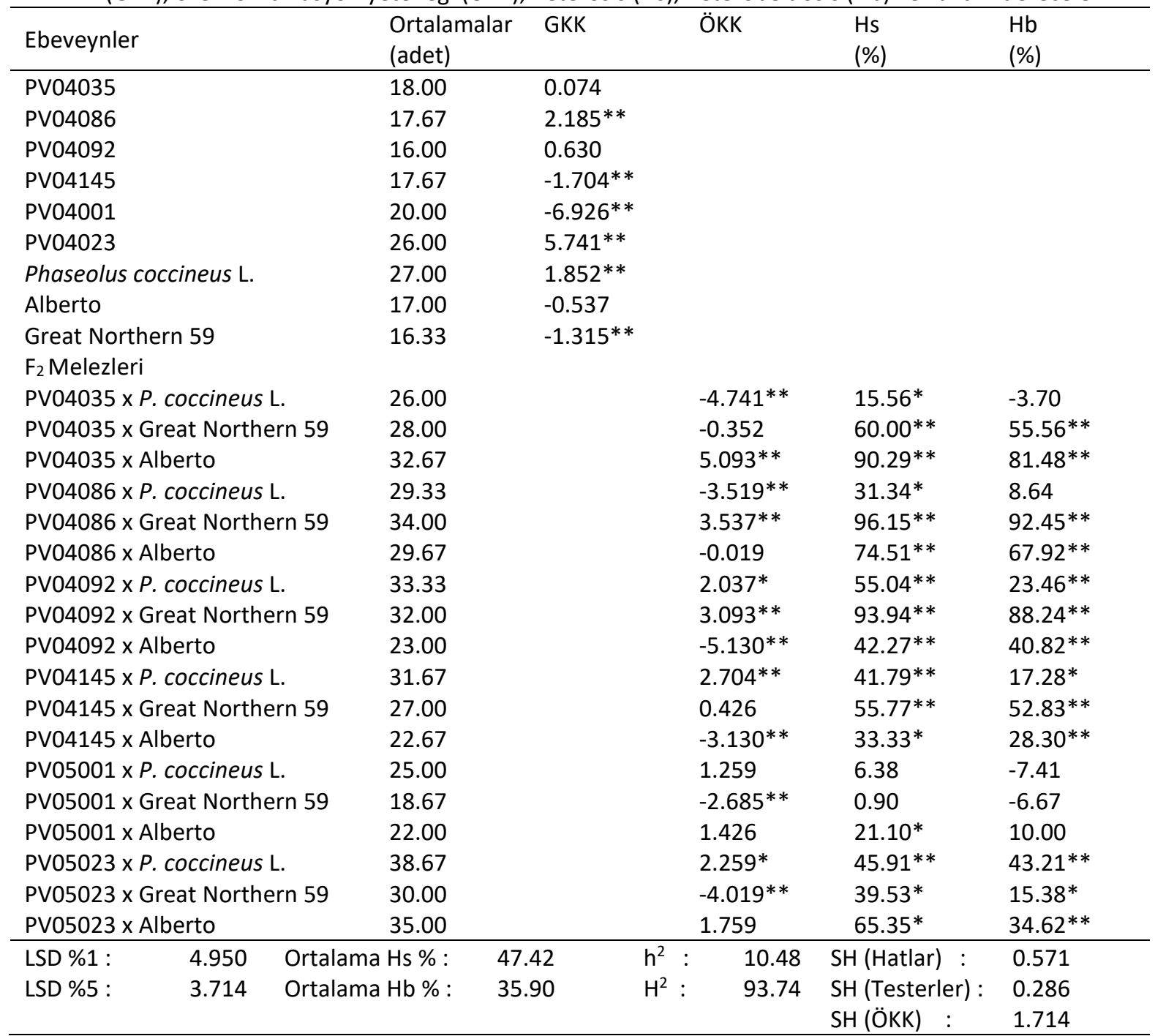

Heterosis değerleri \% 0.90 (PV05001 x Great Northern 59) ile \% 93.9 (PV04092 x Great Northern 59) arasında, heterobeltiosis değerleri ise \% -7.41 (PV05001 x P. coccineus L.) ile \% 92.5 (PV04086 x Great Northern 59) arasında değişim gösterdiği belirlenmiştir (Çizelge 4). Heterosis ve heterobeltiosis değerlerini bitkide bakla sayısı için inceleyen Ceyhan (2004) ve Ceyhan ve ark. (2008) bu özellik için önemli, negatif aynı zamanda pozitif heterosis ve heterobeltiosis değerleri ortaya koymuştur. 
$\mathrm{Bu}$ özellik için geniş anlamda kalıtım derecesinin yüksek ve dar anlamda kalıtım derecesinin düşük çıkması baklada tane sayısının çevreden oldukça etkilendiğini göstermekte ve bundan dolayı seleksiyona 3-4 generasyon sonra başlanılması uygun olacaktır.

Baklada tane sayısı: Baklada tane sayılarında ebeveyn değerlerinin 3.26 (PV04023) ile 5.34 adet (PV04001) arasında; $F_{2}$ populasyonlarında ise baklada tane sayısının 3.59 (PV04092 x Great Northern 59) ile 5.30 adet (PV05001 x P. coccineus L.) arasında değiştiği tespit edilmiştir (Çizelge 5). Daha önce bu konu ile ilgili çalışmalarda bizim araştırma sonuçlarımıza benzer sonuçlar elde etmişlerdir (Genchev, 1995; Ceyhan, 2004b; Ceyhan ve Ülker, 2008; Ceyhan ve ark. 2014; Tamüksek ve Ceyhan, 2020).

Baklada tane sayısı bakımından GKK incelendiğinde, $\quad F_{2}$ populasyonunda PV04001 $(p<0.01)$ hattı pozitif ve önemli değere sahipken; PV04092 ve Alberto $(p<0.01)$ hatları önemli ve negatif değere sahiptirler (Çizelge 5). GKK bakıldığında pozitif önemli çıkan PV04001 hattı bu özellik için yapılacak ıslah çalışmalarında kullanılabilecek uygun ebeveynler olarak tespit edilmiştir. Melezlerin ÖKK etkilerine bakıldığında $F_{2}$ populasyonunda, "PV04092 x Alberto" $(p<0.01)$ melezi pozitif ve önemli etki göstermiştir ve ıslah çalışmalarında kullanılabilecek pozitif genotip olarak belirlenmiştir (Çizelge 5).

Çizelge 5. Fasulye ebeveyn ve $F_{2}$ populasyonlarında baklada tane sayılarına ait ortalamalar, genel kombinasyon yeteneği (GKK), özel kombinasyon yeteneği (ÖKK), heterosis (Hs), heterobeltiosis (Hb) ve kalıtım dereceleri

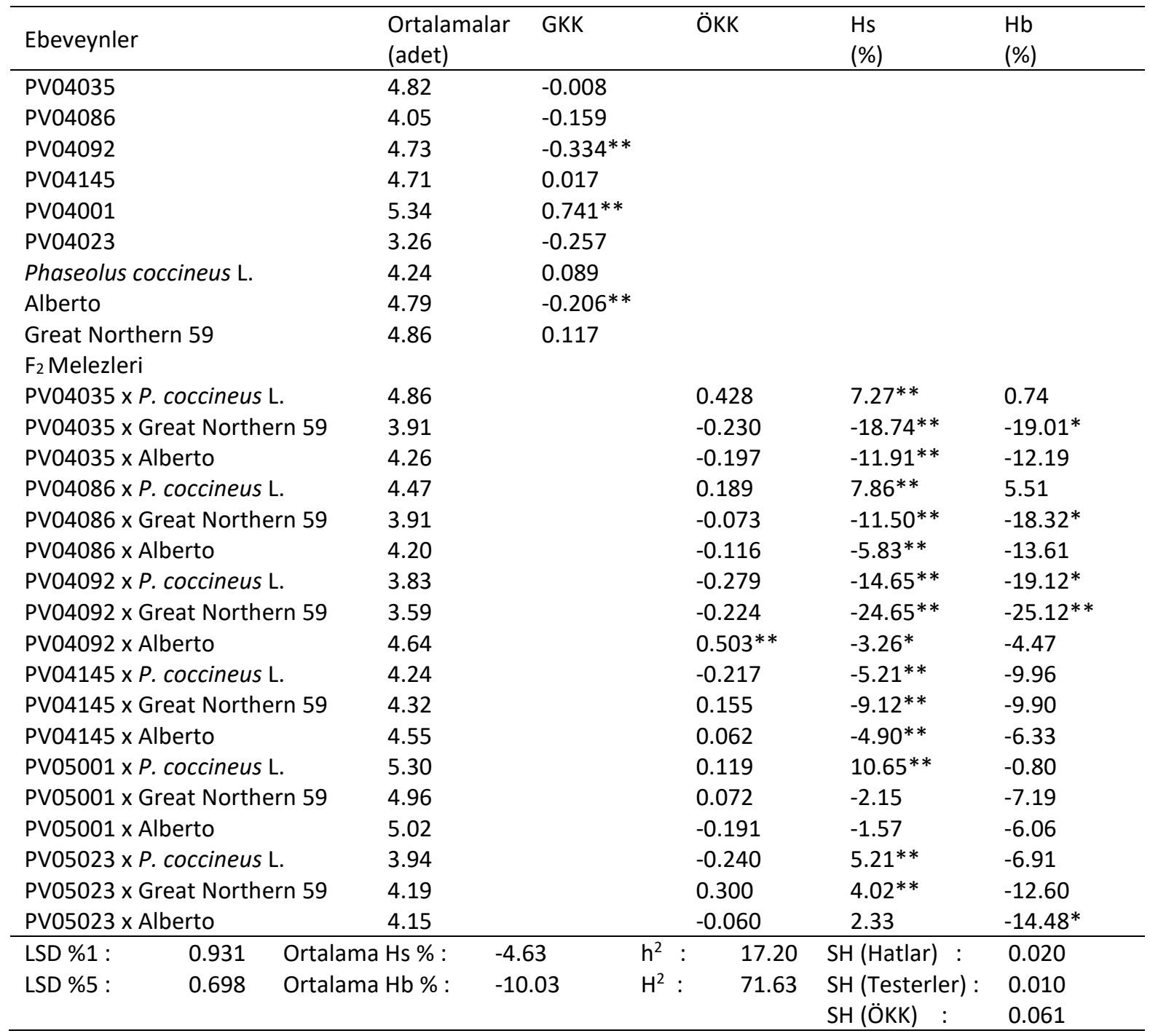

Heterosis değerleri \% -24.7 (PV04092 x Great Northern 59) ile \% 10.7 (PV05001 x P. coccineus L.) arasında, heterobeltiosis değerleri ise \% -25.1 (PV04092 x Great Northern 59) ile \% 5.5 (PV04086 x
P. coccineus L.) arasında değişim göstermiştir (Çizelge 5).

Dar anlamda kalıtım derecesinin düşük olması baklada tane sayısının ortaya çıkmasında 
çevrenin etkisinin daha yüksek olduğunu göstermektedir. Baklada tane sayısının kalıtımında eklemeli olmayan gen etkilerinin önemli olması bizim seleksiyona geç generasyonlarda başlamamız daha uygun olacaktır.

Bitkide tane sayısı: Baklada tane sayılarına ebeveyn değerlerinin 71.3 (PV04086) ile 114.3 adet/bitki ( $P$. coccineus $\quad$ L.) arasında, $F_{2}$ populasyonunda bitkide tane sayısının 92.0 adet/bitki (PV05001 x Great Northern 59) ile 145.3 adet/bitki (PV05023 x Alberto) arasında değişim gösterdiği belirlenmiştir (Çizelge 6). Araştırma sonuçlarımız daha önce bu konuda araştırmalar Ülker ve Ceyhan (2008) ve Tamüksek ve Ceyhan (2020)'ın sonuçları ile uyum içerinde yer almıştır.

Bitkide tane sayılarının GKK incelendiğinde PV04086, P. coccineus L. ve PV04023 $(p<0.01)$ hatları pozitif önemli etkiye sahipken, PV04092, PV04145, PV04001 ve Alberto $(p<0.01)$ hatları negatif önemli etki göstermiştir (Tablo 6). $F_{2}$ populasyonunda melezlerin ÖKK etkilerine bakıldığında, "PV04035 x Alberto" ve "PV05001 x P. coccineus L." melezleri pozitif ve önemli ÖKK etkisine sahipken, "PV04035 x P. coccineus L.", "PV04086 x P. coccineus L.", "PV04086 x Great Northern 59" ve "PV04145 x Alberto" ve "PV05001 $x$ Great Northern 59" melezleri ise negatif ve önemli ÖKK etkiye sahiptir (Çizelge 6). F populasyonun da "PV04035 x Alberto" ve "PV05001 x P. coccineus L." melezleri pozitif ve yüksek ÖKK etkisine sahip olduğu için bitkide tane sayısının artırılmasında kullanılabilecek uygun melez olarak belirlenmiştir. Bizim sonuçlarımıza benzer sonuçlar Tamüksek ve Ceyhan (2020) tarafından da bildirilmiştir.

Çizelge 6. Fasulye ebeveyn ve $F_{2}$ populasyonlarında bitkide tane sayısına ait ortalamalar, genel kombinasyon yeteneği (GKK), özel kombinasyon yeteneği (ÖKK), heterosis (Hs), heterobeltiosis (Hb) ve kalıtım dereceleri

\begin{tabular}{|c|c|c|c|c|c|c|}
\hline \multicolumn{2}{|c|}{ Ebeveynler } & $\begin{array}{l}\text { Ortalamalar } \\
\text { (adet) }\end{array}$ & GKK & ÖKK & $\begin{array}{l}\mathrm{Hs} \\
(\%)\end{array}$ & $\begin{array}{l}\mathrm{Hb} \\
(\%)\end{array}$ \\
\hline \multicolumn{2}{|l|}{ PV04035 } & 86.67 & 0.778 & & & \\
\hline \multicolumn{2}{|l|}{ PV04086 } & 71.33 & $6.111^{* *}$ & & & \\
\hline \multicolumn{2}{|l|}{ PV04092 } & 71.67 & $-7.556 * *$ & & & \\
\hline \multicolumn{2}{|l|}{ PV04145 } & 83.00 & $-5.333 * *$ & & & \\
\hline \multicolumn{2}{|l|}{ PV04001 } & 106.33 & $-11.778 * *$ & & & \\
\hline \multicolumn{2}{|l|}{ PV04023 } & 84.67 & $17.778 * *$ & & & \\
\hline \multicolumn{2}{|c|}{ Phaseolus coccineus L. } & 114.33 & $10.500 * *$ & & & \\
\hline \multicolumn{2}{|c|}{ Alberto } & 81.33 & $-8.389 * *$ & & & \\
\hline \multicolumn{2}{|c|}{ Great Northern 59} & 79.00 & -2.111 & & & \\
\hline \multicolumn{7}{|c|}{$\mathrm{F}_{2}$ Melezleri } \\
\hline \multicolumn{2}{|c|}{ PV04035 x P. coccineus L. } & 125.67 & & $-8.944 * *$ & 25.04 & 9.91 \\
\hline \multicolumn{2}{|c|}{ PV04035 x Great Northern 59} & 108.67 & & -7.056 & 29.37 & $25.38 * *$ \\
\hline \multicolumn{2}{|c|}{ PV04035 x Alberto } & 138.00 & & $16.000 * *$ & $66.60 *$ & $59.23 * *$ \\
\hline \multicolumn{2}{|c|}{ PV04086 x P. coccineus L. } & 131.00 & & $-8.944 * *$ & 41.11 & $14.58 * *$ \\
\hline \multicolumn{2}{|c|}{ PV04086 x Great Northern 59} & 133.00 & & $11.944^{* *}$ & $74.24^{*}$ & $63.52 * *$ \\
\hline \multicolumn{2}{|c|}{ PV04086 x Alberto } & 124.33 & & -3.000 & $65.41^{*}$ & $57.38 * *$ \\
\hline \multicolumn{2}{|c|}{ PV04092 x P. coccineus L. } & 127.33 & & 1.056 & 36.92 & $11.37^{*}$ \\
\hline \multicolumn{2}{|c|}{ PV04092 x Great Northern 59} & 113.67 & & 6.278 & 48.58 & $39.75^{* *}$ \\
\hline \multicolumn{2}{|c|}{ PV04092 x Alberto } & 106.33 & & $-7.333^{*}$ & 41.15 & $34.60 * *$ \\
\hline \multicolumn{2}{|c|}{ PV04145 x P. coccineus L. } & 134.33 & & 5.833 & 36.15 & $17.49 * *$ \\
\hline \multicolumn{2}{|c|}{ PV04145 x Great Northern 59} & 116.67 & & 7.056 & 41.99 & $40.56^{* *}$ \\
\hline \multicolumn{2}{|c|}{ PV04145 x Alberto } & 103.00 & & $-12.889 * *$ & 27.16 & $24.10 * *$ \\
\hline \multicolumn{2}{|c|}{ PV05001 x P. coccineus L. } & 132.33 & & $10.278^{* *}$ & 19.94 & $15.74 * *$ \\
\hline \multicolumn{2}{|c|}{ PV05001 x Great Northern 59} & 92.00 & & $-11.167^{* *}$ & -1.95 & $-13.48^{*}$ \\
\hline \multicolumn{2}{|c|}{ PV05001 x Alberto } & 110.33 & & 0.889 & 19.06 & 3.76 \\
\hline \multicolumn{2}{|c|}{ PV05023 x P. coccineus L. } & 152.33 & & 0.722 & $53.10 *$ & $33.24 * *$ \\
\hline \multicolumn{2}{|c|}{ PV05023 x Great Northern 59} & 125.67 & & -7.056 & $51.41 *$ & $48.43^{* *}$ \\
\hline \multicolumn{2}{|c|}{ PV05023 x Alberto } & 145.33 & & 6.333 & $77.60 * *$ & $71.65^{* *}$ \\
\hline \multirow{3}{*}{$\begin{array}{l}\text { LSD \%1 : } \\
\text { LSD \%5 : }\end{array}$} & 15.792 & Hs \% : & $h^{2}:$ & 13.83 & SH (Hatlar) : & 5.813 \\
\hline & 11.847 Ortal & $\mathrm{Hb} \%$ : & $\mathrm{H}^{2}:$ & 92.82 & SH (Testerler) : & 2.906 \\
\hline & & & & & SH (ÖKK) : & 17.438 \\
\hline
\end{tabular}


arasında, heterobeltiosis değerleri ise \% -13.5 (PV05001 x Great Northern 59) ile \% 71.7 (PV05023 $x$ Alberto) arasında değişim göstermiştir (Çizelge 6).

Bitkide tane sayısı için $F_{2}$ populasyonun da geniş anlamda kalıtım derecesinin yüksek ve dar anlamda kalıtım derecesinin düşük olması baklada tane sayısının çevreden oldukça fazla etkilendiğini göstermektedir. Bundan dolayı seleksiyona 3-4 generasyon sonra başlanılmasının daha iyi olacağı gözlemlenmektedir.

Yüz tane ağırlığı: Yüz tane ağırlıkları için ebeveyn değerleri $22.1 \mathrm{~g}$ (Great Northern 59) ile $38.4 \mathrm{~g}$ ( $P$. coccineus $\mathrm{L}$.), $\mathrm{F}_{2}$ populasyonunda yüz tane ağırlığı 20.7 g (PV05023 x Alberto) ile $26.0 \mathrm{~g}$ (PV04035 x P. coccineus L.) arasında değişim gösterdiği tespit edilmiştir (Çizelge 7). Genchev
(1995), Ceyhan ve Ülker (2008), Ceyhan ve ark. (2014) ve Tamüksek ve Ceyhan (2020) daha önce yaptıkları çalışmalarda bizim araştırma sonuçlarına benzer sonuçlar elde etmişlerdir.

Araştırmada yüz tane ağırlığı bakımından GKK incelendiğinde "PV04035", "PV04145", "Alberto" ve " $P$. coccineus L." hatları önemli ve pozitif değere sahipken, "PV04092", "PV04001" ve "Great Northem 59" hatlarının ise negatif ve önemli etkisi belirlenmiştir (Çizelge 7). GKK bakıldığında yüz tane ağırlığının artırılmasında $F_{1}$ generasyonun da pozitif ve önemli çıkan "PV04035", "PV04145", "Alberto" ve "P. coccineus L." hatları çeşidi bu özellik için yapılacak melezleme çalışmalarında kullanılabilecek uygun ebeveynler olarak gözlemlenmiştir.

Çizelge 7. Fasulye ebeveyn ve $F_{2}$ populasyonlarında yüz tane ağırlı̆̆ına ait ortalamalar, genel kombinasyon yeteneği (GKK), özel kombinasyon yeteneği (ÖKK), heterosis (Hs), heterobeltiosis (Hb) ve kalıtım dereceleri

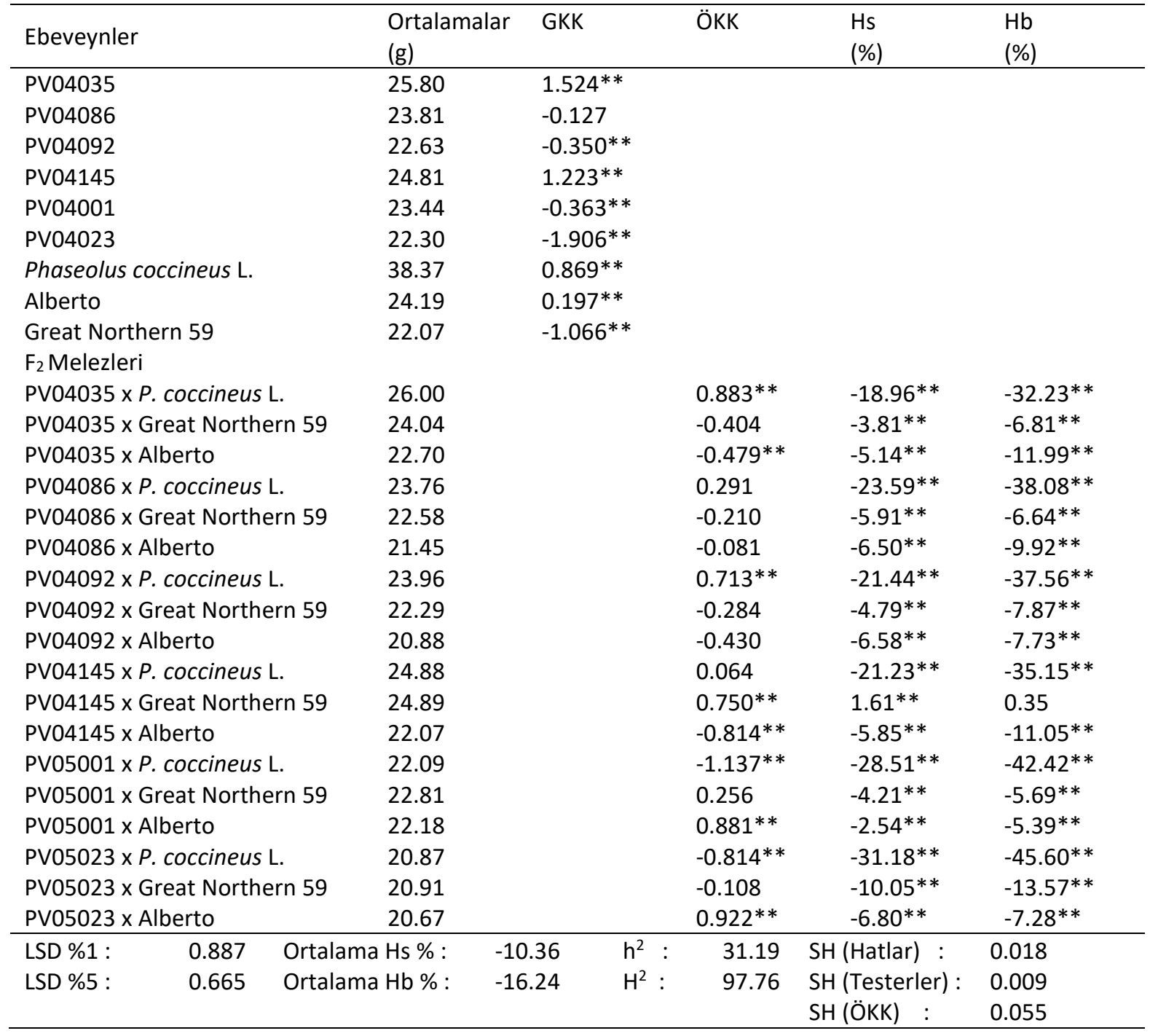

Melezlerin ÖKK etkilerine bakıldığında $F_{2}$ generasyonunda, dokuz melez istatistiki bakımdan önemli ÖKK etkisi gösterdiği belirlenmiştir. Pozitif ve önemli ÖKK etkisi gösteren beş melez tespit edilirken; negatif ve önemli dört melez tespit edilmiştir. "PV04035 x P. coccineus L.", "PV04092 x 
P. coccineus L.", "PV04145 x Great Northern 59", "PV05001 x Alberto" ve "PV05023 x Alberto" melezler yüz tane ağırlığını arttırmada kullanılabilecek genotip olarak belirlenmişlerdir (Çizelge 7).

Heterosis değerleri \% -31.2 (PV05023 x P. coccineus L.) ile \% 1.6 (PV04145 x Great Northern 59) arasında, heterobeltiosis değerleri ise \% -45.6 (PV05023 x P. coccineus L.) ile \% 0.35 (PV04145 x Great Northern 59) arasında değişim göstermiştir (Çizelge 7). Heterosis ve heterobeltiosis değerlerini bitkide bakla sayısı için inceleyen Ceyhan (2004) ve Ceyhan ve ark. (2008) bu özellik için önemli, negatif aynı zamanda pozitif heterosis ve heterobeltiosis değerleri ortaya koymuştur.
$F_{1}$ generasyonunda yüz tane ağırlığı için geniş anlamda kalıtım derecesinin yüksek olması çevre varyansından etkilendiğini gösterirken seleksiyon işleminin ileriki dönemlerde yapılması daha uygun olacağı ortaya çıkmaktadır.

Tane verimi: Tane verimi için ebeveyn değerlerinin 18.0 (PV04086) ile $53.9 \mathrm{~g} /$ bitki ( $P$. coccineus L.), $F_{2}$ populasyonunda tek bitki tane verimlerinin 26.3 (PV05001 x Great Northern 59) ile 40.8 g/bitki (PV05023 x P. coccineus L.) arasında değiştiği belirlenmiştir (Çizelge 8). Araştırma sonuçlarımız ile (Genchev, 1995; Ceyhan ve Ülker, 2008; Ceyhan ve ark. 2014; Tamüksek ve Ceyhan, 2020)'nın sonuçları birbiriyle uyum içerisindedir.

Çizelge 8. Fasulye ebeveyn ve $F_{2}$ populasyonlarında tane verimine ait ortalamalar, genel kombinasyon yeteneği (GKK), özel kombinasyon yeteneği (ÖKK), heterosis ( $\mathrm{Hs})$, heterobeltiosis ( $\mathrm{Hb}$ ) ve kalıtım dereceleri

\begin{tabular}{|c|c|c|c|c|c|c|}
\hline \multicolumn{2}{|c|}{ Ebeveynler } & $\begin{array}{l}\text { Ortalamalar } \\
\text { (g/bitki) }\end{array}$ & GKK & ÖKK & $\begin{array}{l}\mathrm{Hs} \\
(\%)\end{array}$ & $\begin{array}{l}\mathrm{Hb} \\
(\%)\end{array}$ \\
\hline \multicolumn{2}{|l|}{ PV04035 } & 30,69 & 2,596 & & & \\
\hline \multicolumn{2}{|l|}{ PV04086 } & 17,98 & 1,063 & & & \\
\hline \multicolumn{2}{|l|}{ PV04092 } & 21,22 & $-1,227$ & & & \\
\hline \multicolumn{2}{|l|}{ PV04145 } & 21,59 & 0,499 & & & \\
\hline \multicolumn{2}{|l|}{ PV04001 } & 33,93 & $-4,540 * *$ & & & \\
\hline \multicolumn{2}{|l|}{ PV04023 } & 19,88 & 1,609 & & & \\
\hline \multicolumn{2}{|c|}{ Phaseolus coccineus L. } & 53,85 & $3,504^{* *}$ & & & \\
\hline \multicolumn{2}{|c|}{ Alberto } & 22,34 & $-2,025^{* *}$ & & & \\
\hline \multicolumn{2}{|c|}{ Great Northern 59} & 20,10 & $-1,480$ & & & \\
\hline $\mathrm{F}_{2}$ Melezl & & & & & & \\
\hline PV04035 & ccineus L. & 39,66 & & $-0,989$ & $-6,18$ & $-26,35 * *$ \\
\hline PV04035 & t Northern 59 & 31,80 & & $-3,319$ & 19,92 & 3,61 \\
\hline PV04035 & rto & 39,97 & & 4,308 & $57,40 *$ & $30,23 *$ \\
\hline PV04086 & ccineus L. & 37,45 & & $-1,662$ & 4,28 & $-30,45^{*}$ \\
\hline PV04086 & t Northern 59 & 37,71 & & 4,125 & $87,02 *$ & $68,77^{* *}$ \\
\hline PV04086 & rto & 31,67 & & $-2,463$ & $66,32 *$ & $57,56 * *$ \\
\hline PV04092 & ccineus L. & 40,11 & & 3,280 & 6,86 & $-25,52 *$ \\
\hline PV04092 & t Northern 59 & 30,32 & & $-0,977$ & 39,21 & $35,69 *$ \\
\hline PV04092 & rto & 29,54 & & $-2,303$ & 42,99 & $39,23 *$ \\
\hline PV04145 & ccineus L. & 38,74 & & 0,186 & 2,70 & $-28,06^{*}$ \\
\hline PV04145 & t Northern 59 & 37,34 & & 4,320 & $69,98^{*}$ & $67,12 * *$ \\
\hline PV04145 & rto & 29,06 & & $-4,506$ & 39,41 & $34,59 *$ \\
\hline PV05001 & ccineus L. & 31,58 & & $-1,938$ & $-28,06$ & $-41,36 * *$ \\
\hline PV05001 & t Northern 59 & 26,31 & & $-1,672$ & $-6,48$ & $-22,45^{*}$ \\
\hline PV05001 & rto & 32,14 & & 3,610 & 18,97 & $-5,27$ \\
\hline PV05023 & ccineus L. & 40,78 & & 1,122 & 10,64 & $-24,26^{*}$ \\
\hline PV05023 & t Northern 59 & 31,66 & & $-2,476$ & 49,96 & $41,68 * *$ \\
\hline PV05023 & rto & 36,03 & & 1,355 & $80,28 *$ & $79,28 * *$ \\
\hline LSD \%1 : & 9,319 & Hs \% : & $h^{2}$ & 7,68 & SH (Hatlar) : & 2,024 \\
\hline LSD \%5 : & 6,991 & $\mathrm{Hb} \%$ : & $\mathrm{H}^{2}$ & 70,60 & SH (Testerler) : & 1,012 \\
\hline & & & & & SH (ÖKK) : & 6,072 \\
\hline
\end{tabular}

Bitki tane verimlerine GKK etki değerine bakıldığında hatlar arasında önemli ve pozitif değere sahip hat yok iken, PV04001 hattı negatif ve önemli $(p<0.01)$ etkiye sahip olduğu belirlenmiştir. Testerler arasında ise $P$. coccineus $L$. çeşidi pozitif ve önemli $(p<0.01)$ etki gösterirken, Alberto çeşidi ise negatif ve önemli $(p<0.01)$ etkili olmuştur (Çizelge 8). GKK etki değeri pozitif ve önemli bulunan $P$. coccineus L. çeşidinin melezleme çalışmalarında 
tane verimini artırmak için kullanılabilecek uygun ebeveyn olarak belirlenmiştir.

$F_{2}$ populasyonunda melezlerin ÖKK etkilerine bakıldığında hiçbir melezin pozitif ve önemli ÖKK etkisi tespit edilememiştir. Ancak "PV04035 x Alberto", "PV04086 x Great Northern 59" ve "PV04145 x Great Northern 59" melezlerinin ÖKK etkilerinin pozitif yüksek çıkması nedeniyle ileriki generasyonlarda tane verimi için ıslah potansiyeli olan genotip olarak ortaya çıkmaktadır (Çizelge 8). Fasulyede GKK ve ÖKK etkisi üzerine yapıla bir çok araştırma sonuçlarında tane verimi için farklı sayılarda önemli GKK ve ÖKK etkisi göstermiş olan ebeveyn ve melez kombinasyonları ortaya koymuşlardır (Zimmermann ve ark., 1985; Oliveira Junior ve ark., 1997; Rodrigues ve ark., 1998; Barelli ve ark., 2000; Ceyhan ve ark., 2014 ve Tamüksek ve Ceyhan, 2020).

Araştırmada heterosis değerleri \% -28.1 (PV05001 x P. coccineus L.) ile \% 87.0 (PV04086 x Great Northern 59) arasında, heterobeltiosis değerleri ise \% -41.4 (PV05001 x P. coccineus L.) ile \% 79.3 (PV05023 x Alberto) arasında değişmiştir (Çizelge 8). Heterosis ve heterobeltiosis değerlerini bitkide bakla sayısı için inceleyen Ceyhan (2004) ve Ceyhan ve ark. (2008) bu özellik için önemli, negatif aynı zamanda pozitif heterosis ve heterobeltiosis değerleri ortaya koymuştur.

$\mathrm{Bu}$ özelliğin kalıtımında geniş anlamda kalıtım derecesinin yüksek, dar anlamda kalıtım derecesinin ise düşük olarak bulunmuştur. Buda bize fasulyede tane veriminin çevre varyansından da etkilenen kompleks bir karakter olduğunu göstermektedir. Kompleks karakter olan tane veriminin seleksiyonuna daha sonraki seleksiyonlarda diğer özelliklerle birlikte değerlendirilerek başlanması daha doğru olacaktır.

\section{Sonuç ve Öneriler}

Sonuç olarak, incelenen tarımsal özellikler bakımından ele alınan populasyonda yeterli düzeyde bir genetik varyasyon bulunmaktadır. Bu çalışmada incelenen özellikler üzerinde eklemeli olmayan genlerin ve dominant genler daha etkili oldukları bulunmuştur. Bu popülasyonda seçme işlemi tane verimi ile beraber değerlendirilerek daha ileriki generasyonlarda yapılmasının doğru olacağı kanaatindeyiz.

Teşekkür: Bu çalışmaya 18401158 nolu proje ile katkı sağlayan Selçuk Üniversitesi BAP Koordinatörlüğüne teşekkür ederiz.

Çıkar Çatışması Beyanı: Yazarlar olarak herhangi çıkar çatışması olmadığını beyan ederiz.
Araştırmacıların Katkı Oranı Beyan Özeti: Makaleye eşit oranda katkı sağlamış olduğumuzu beyan ederiz.

\section{Kaynaklar}

Akçin, A. 1988. Yemeklik Tane Baklagiller. Selçuk Üniv. Zir. Fak. Yayın No: 8, 41-189, Konya.

Al-Mukhtar, F.A. ve Coyne, D.P. 1981. Inheritance and association of flower ovule, seed, pod and maturity characters in dry edible beans (Phaseolus vulgaris L.). Journal of the American Society for Horticultural Science, 106 (6): 713-719.

Arago, F.J.L. ve Brasileiro A.C.M., 1995. Inoculation of bean and soybean with cloned bean golden mosaic virus (BGMV) DNA using particle acceleration. Fitopatologia Brasileira, 20(4): 642-644.

Barelli, M.A.A., Gonçalves-Vidigal, M.C., Amaral, J., Vidigal, F., Scapim, C.A. ve Sagrilo, E. 2000. Diallel analysis for grain yield and yield components in Phaseolus vulgaris L. Acta Scientiarum, 22 (4): 883-887.

Ceyhan, E., 2004. Effect of sowing dates on some yield components and yield of dry bean (Phaseolus vulgaris L.) cultivars. Turkish Journal of Field Crops, 9 (2): 87-95.

Ceyhan, E., 2003. Bezelye Ebeveyn ve Melezlerinde Bazı Tarımsal Özelliklerin ve Kalıtımlarının Çoklu Dizi Analiz Metoduyla Belirlenmesi, Doktora Tezi, Selçuk Üniversitesi, Konya, 103s.

Ceyhan E, Avci M.A. ve Karadas S. 2008. Line x tester analysis in pea (Pisum sativum L.): Identification of superior parents for seed yield and its components. African Journal of Biotechnology, 7: 2810-2817.

Ceyhan, E., Kahraman, A., Avcı, M.A. ve Dalgıç, H. 2014. Combining ability of bean genotypes estimated by line $x$ tester analysis under highly-calcareous soils. The Journal of Animal and Plant Sciences, 24 (29): 579-584.

Genchev, D., 1995. Assessment of tolerance to stress factors in breeding material of kidney beans (Phaseolus vulgaris L.). Bulgarian Journal of Agricultural Science, 1(4): 415422.

Kempthorne, O. 1957. An Introduction to Genetic Statitic, Wiley and Sons, New York, p.158.

Kranup, H.A. 1995. Comparison of three methods of selection for yield in peas (Pisum sativum L.). Agrosur, 23: 39-44.

Niwas, R., Kumar, R. ve Dahiya, B.S. 1990. Comparison of selection methods in dwarf field peas (Pisum sativum L.) I. Effectiveness for earliness. International Journal of Tropical Agriculture, 8(2): 136-140. 
Oliveira Junior, A., Miranda, G.V. ve Cruz, C.D. 1997. Evaluation of the combining ability of dry bean cultivars based on unbalanced circulating and partial diallel crossing systems. Revista Ceres, 44 (252): 215-229.

Rodrigues, R., Leal, N.R. ve Pereira, M.G. 1998. Diallel analysis of six agronomic traits in Phaseolus vulgaris L., Bragantia, 57(2): 241250.

Sing, R.K. ve Chaudhary, B.D. 1979. Line $x$ tester analysis. In : Biometrical methods in quantitative genetic analysis. Kalyani Publishers, New Delhi, pp. 205-214.

Singh, S.P. ve Urrea, C.A. 1994. Selection for seed yield and other traits among early generations of intra- and interracial populations of the common bean. Brazil de Genetica, 17(3): 299-303.

Şehirali, S. 1988. Yemeklik Dane Baklagiller. A.Ü. Ziraat Fakültesi Yayın No: 1089. s.435. Ankara.
Tamüksek, Ş. ve Ceyhan, E. 2020. Determination of characteristics of dry bean lines hybridized by line $x$ tester method and the effect of heredity. Türk Tarım ve Doğa Bilimleri Dergisi, 7(1): 157-164.

Ülker, M. ve Ceyhan, E. 2008. Orta Anadolu ekolojik şartlarında yetiştirilen fasulye (Phaseolus vulgaris L.) genotiplerinin bazı tarımsal özelliklerinin belirlenmesi. Selçuk Üniversitesi Ziraat Fakültesi Dergisi, 22 (46), 77-89.

Varankaya, S. ve Ceyhan, E. 2012. Yozgat ekolojik şartlarında yetiştirilen fasulye (Phaseolus vulgaris L.) genotiplerinin bazı tarımsal özelliklerinin belirlenmesi. Selçuk Tarım ve Gıda Bilimleri Dergisi, 26 (1): 27-33.

Zimmermann, M.J.O., Rosielle, A.A., Foster, K.W. ve Waines, J.G. 1985. Gene action for grain yield and harvest index of common bean grown as sole crop and in intercrop with maize. Field Crops Research, 12: 319-329. 